IRSH 67 (2022), pp. 43-64 doi:10.1017/So020859020000358

(C) 2020 Internationaal Instituut voor Sociale Geschiedenis

\title{
Murder and the Working Lives of Chinese Male Servants in Colonial Singapore, I910s-1930s*
}

\author{
CLAIRE LOWRIE \\ School of Humanities and Social Inquiry \\ University of Wollongong \\ Northfields Ave, Wollongong, NSW 2522 Australia \\ E-mail: clowrie@uow.edu.au
}

\begin{abstract}
Chinese men working as servants in colonial Singapore were a largely unregulated group of workers and, as a result, few traces of their lives have been preserved in the colonial archive. Rare cases in which Chinese domestic workers were accused of murder compelled the colonial state to directly intervene in their lives. This article explores the experiences of Chinese migrant men who worked as domestic servants in Singapore by analysing three murders that occurred between the I 9 Ios and the i93os. Details of the crimes and the arrests, along with the processes of conviction and sentencing, were reported in detail in the local newspapers. In addition, testimonies of the accused and of witnesses were preserved in Coroner's Court records. This rich criminal archive is used to shed light upon aspects of domestic servants' lives that would otherwise remain obscure.
\end{abstract}

On 25 August I918, one of colonial Singapore's most notorious murders occurred at the Globe Hotel on 326 North Bridge Road. That night, Sarah Liebmann, the proprietor of the public house, was bludgeoned with an iron bar and then strangled to death. Emil Landau, an elderly man who resided at the Globe, was also murdered by strangulation that night. ${ }^{\text {I }} \mathrm{A}$ few days later, Liang Ah Tee, a "bar boy" employed at the hotel, confessed to the

\footnotetext{
* I would like to thank the anonymous reviewers and the Editorial Committee for their excellent feedback. I also wish to thank Victoria Haskins, Samita Sen, Brenda Yeoh, and the members of the Centre for Colonial Settler Studies at the University of Wollongong for their detailed feedback on draft versions of this article. I am also grateful to Nitin Sinha and Nitin Varma who funded an EHSC conference panel on Domestic Service and Regulation as part of their ERC project on "Servants' Pasts" where I presented an early version of this article.

I. All quoted material and the names of victims and perpetrators are drawn from newspaper records rather than Coroner's Court Records. "The Assizes: Globe Hotel Murders", Malaya Tribune, 24 September 1918; "Death of a Female and Male Austrian Jew, Coroner's Court,
} 
murders. By the time the case went to trial, however, Liang was claiming innocence. He pleaded with the judge through a court interpreter, "I didn't kill these people $[\ldots]$ the police forced me to make a confession". ${ }^{2} \mathrm{He}$ was nonetheless convicted by a jury and sentenced to die by judicial hanging. The execution took place on the morning of 30 October, with Liang reportedly breaking down before "usual formalities" took place and "life was declared extinct". ${ }^{3}$ The case was remembered as one of "the most brutal crimes that have ever been committed in the Colony". ${ }^{4}$

This article analyses three cases of murder perpetrated by Chinese men who worked as domestic servants in Singapore between the r9ros and the I930s. In addition to the Globe Hotel murders, I analyse the stabbing of Wong Chee by fellow servant Ee Ah Lak in I925 and the killing of Teo Chye Neo by her young Hainanese servant, Yeo Tin Keng, in I933. By analysing these crimes and the responses of the colonial state and the press to them, I aim to illuminate aspects of domestic servants' lives that would otherwise remain unknown. Despite the fact that they predominated in domestic service until the I930s, there has been little scholarly research on this group of workers. Male servants are inadequately researched in part because of the lack of government regulation to which they were subjected. The provisions of Master and Servant Law were inherited from Britain and could be drawn on in Singapore to deal with servant insolence, neglect of duty, and absence without leave. 5 However, recruitment of servants, the terms of employment, and wages were determined not by the government but by the Hainanese kongsi, a dialect-based community that represented the majority of Chinese male servants in Singapore. ${ }^{6}$ The lack of official intervention has ensured that there are limited sources that leave us with an impression of servants' lives. One of the few instances when Chinese male servants were subject to governmental control, and thus appear in the archives in great detail, was when they were charged and convicted of breaking the law.

My analysis of digitized English-language newspapers and Coroner's Court records uncovered seventeen alleged violent crimes committed by servants

Coroner's Court Inquiries, Jan to Dec 1918, Singapore”, 26 August 1918, National Archives of Singapore (hereafter NAS): ADo63.

2. "Globe Hotel Murders: Accused Sentenced to Death", Singapore Free Press and Mercantile Advertiser (hereafter SFPMA), 3 October 1918.

3. "Globe Hotel Murders: Accused Man Executed", SFPMA, 31 October 1918.

4. "Sequence of Murders: Singapore House's Ominous Story”, SFPMA, 20 February 1925.

5. Christopher Munn, "Hong Kong, I 84 I-I 870: All the Servants in Prison and Nobody to Take Care of the House”, in Douglas Hay and Paul Craven (eds), Masters, Servants, and Magistrates in Britain and the Empire (Chapel Hill, NC, 2004), p. 366.

6. Maurizo Peleggi, "The Social and Material Life of Colonial Hotels: Comfort Zones as Contact Zones in British Colombo and Singapore, ca. I 870-1930”, Journal of Social History, 46: I (2012), p. 2 I. 
between I910 and 1939, twelve of which led to conviction. They included three murders, four attempted murders, one attempted murder/suicide, and four convictions for causing bodily hurt or grievous bodily hurt. Eleven of the twelve violent crimes were perpetrated by Chinese male servants. In I92I, there were roughly I2,000 Chinese men working as servants in Singapore. ${ }^{7}$ Considering this, eleven convictions for violent crimes is a surprisingly small figure. Convictions of employers for violent crimes against servants were also rare. ${ }^{8}$

While Chinese men convicted of violent crimes may not have been representative in terms of the domestic servant workforce, these cases nonetheless tell us a great deal about this group of workers. The most detailed insights into Chinese men's lives in Singapore are provided by three cases of murder that took place a decade apart. In addition to the extremely comprehensive reports of the press, murder cases were also subject to Coroner's Court proceedings, resulting in a rich, if at times patchy, legal archive. ${ }^{9}$ As journalists, lawyers, and judges sought to understand the nature of the crimes and those responsible for them, they recorded minute details of domestic servants' lives. Singapore's residential and commercial enclaves were organized along lines of race and class. ${ }^{1 \circ}$ Chinese male servants moved across these divisions as they worked in elite and middle-class households, laboured in high-end and low-class hotels, and socialized amongst the Chinese working classes. As police and prosecutors retraced the steps of the Chinese men involved in crimes of violence, they inadvertently provided glimpses into the social worlds of Singapore in the interwar years.

Also preserved within the records of murder cases are the statements and testimonies of servants as witnesses and perpetrators. The accounts of domestic workers were provided in Hainanese, Hokchia (Foochow/Fuzhou), or other Chinese languages that were then interpreted and recorded in English. While they were undoubtedly altered by the translation process and influenced by the intimidating environments of police stations and court rooms, these first-hand accounts are invaluable. They provide one of the few avenues through which we can access servants' voices. ${ }^{\text {II }}$

7. J.E. Nathan, The Census of British Malaya I92 I (London, I922), pp. I8, 83, 239.

8. See Claire Lowrie, “'A Frivolous Prosecution': Allegations of Physical and Sexual Abuse of Domestic Servants and the Defence of Colonial Patriarchy in Darwin and Singapore”, in Penelope Edmonds and Amanda Nettelback (eds), The Intimacies of Violence in Settler Colonial Economies (New York, 2018), pp. 249-272.

9. Inquest records and court proceedings for the murders of Leibmann and Landau (I9I8) and for Wong (1925) are held by the National Archives of Singapore. The case notes of judges and case files have not been retained. There is only a brief reference to the Teo murder (1933) in the Coroner's Court Master Book.

Iо. Brenda S.A. Yeoh, Contesting Space in Colonial Singapore (Singapore, 2003), pp. I-3.

I I. The National Archives of Singapore hold only two oral history interviews with Chinese men who worked as servants during the colonial era: “Transcript of Interview with Lim Ming Joon”, 23 
The use of Coroner's Court records to track the lives of working-class people in Singapore was an approach pioneered by James Francis Warren in his work on rickshaw pullers and prostitutes. ${ }^{\mathrm{I}}$ By focusing on domestic servants, this article takes Warren's work in a new direction. My methodology resembles that of Tim Meldrum, who analysed London Consistory Court records in order to illuminate the lives of servants. Meldrum drew on servants' voices within the ecclesiastical court records as they gave testimony about the marital disputes of their employers. ${ }^{13}$ The records used in this article are rather different insofar as they deal with crimes committed by servants. They provide opportunities for considering how servants fared in the criminal justice system - a key regulatory arm of the colonial state.

Scholars of domestic service have long contended that domestic life in the colonies was imbued with deep political significance. They have shown how mastery over "native" servants was viewed in colonial societies as a symbol and a practical expression of colonizer status. ${ }^{14}$ Encounters between master and servant had the potential to reinforce or challenge colonial hierarchies. ${ }^{\text {Is }}$ The sometimes violent encounters between masters and servants in the confines of white colonial homes were a site of public commentary and governmental intervention. ${ }^{16}$ The murder cases analysed in this article do not fit the usual definition of domestic service as involving a white employer and a native servant engaged in a private home. They took place not only in British homes, but in Chinese households as well as in commercial establishments. The men convicted of crimes were referred to as "servants" regardless of whether they laboured in private households, hotels, bars, or within company messes. The crimes involved violence towards employers as well as between servants. As they expose the diversity of situations in which men categorized "servants" were employed, these three cases challenge us to think about colonial domestic service in new ways.

In this article, I use the definition of domestic service as being "the work of an individual for another individual or family, in carrying out personal household tasks such as cleaning, cooking, childcare, and carework in general". It is labour performed neither on the basis of "a social or kinship obligation, nor as

September 1983, NAS: ACC 000334 /07; “Transcript of Interview with Wong York Beng”, 26 May 1986, NAS: ACC 000668/02/04.

I 2. James Francis Warren, $A b K u$ and Karayuki-San (Singapore, 1993); James Francis Warren, Rickshaw Coolie (Singapore, 2003).

I3. Tim Meldrum, Domestic Service and Gender I660-1750 (Harlow, 2000), pp. 7-9.

14. See, for example, Ann Laura Stoler, Carnal Knowledge and Imperial Power (Berkeley, CA, 2010), pp. 6-9.

I 5. Prinisha Badassy, “'And My Blood Became Hot!': Crimes of Passion, Crimes of Reason”, Journal of Natal and Zulu History, 23:I (2006), pp. 73-106.

I6. Jordanna Bailkin, “The Boot and the Spleen: When Was Murder Possible in British India?”, Comparative Studies in Society and History, 48:2 (2006), pp. 463-464. 
a favour or kindness" but as "a definite 'service" ${ }^{17}$. Included within the definition of domestic service is care work performed in the context of commercial establishments. This reflects colonial conceptions of domestic service in Singapore. In defining the category of "personal service", colonial statisticians, like the general public, did not differentiate between "domestic servants" engaged in private homes and those working in commercial establishments. ${ }^{18}$

By analysing murders that occurred in homes as well as businesses, and by considering violence between servants as well as towards employers, this article takes up the call to consider domestic service beyond the domain of the household and builds on recent work that has examined domestic work in the more public realm of hotels and steamships. ${ }^{19}$ This article also seeks to examine the lives of servants outside of their relationships with employers. The Sarah Leibmann (1918) and Teo Chye Neo (1933) murders illustrate that abuse and condescension on the part of employers were a catalyst for violence by some Chinese servants, whether they were employed in British or Chinese households. Yet, as the Wong Chee murder case (1925) demonstrates, acts of violence were also motivated by factors outside of the master-servant relationship. In this particular case, tensions between domestic workers arising from intimacy as well as financial stress culminated in a frenzied act of violence.

\section{DOMESTIC SERVICE AND VIOLENT CRIME IN SINGAPORE}

Colonial Singapore, like other port towns in Southeast Asia, was marked by its cultural, social, and religious heterogeneity. In I92 I, the population of over 425,000 people included a very small number of "Europeans" (mostly of British origin), a slightly larger Eurasian community, and a sizeable Malay and Indian population. This cosmopolitan city was one governed and organized according to notions of "race" and divisions of class. Yet, as Lynn Hollen Lees has shown, it was also one in which the Asian middle classes mingled, forging cross-ethnic alliances and connections. ${ }^{20}$ The Chinese community, which consisted of 74.5 per cent of the total population in I $92 \mathrm{I}$, was a diverse one. ${ }^{21}$ It included Straits Chinese (Peranakan) people, who had been resident in Malaya for generations and who had married into local Malay communities, as well as a larger overseas-born Chinese (buaqiao) community. ${ }^{22}$ In

17. Victoria Haskins and Claire Lowrie, "Introduction: Decolonizing Domestic Service: Introducing a New Agenda", in Victoria Haskins and Claire Lowrie (eds), Colonization and Domestic Service (New York, 20I 5), p. I.

I8. Nathan, Census of British Malaya 1921 , p. i 8.

19. Julia Martínez, Claire Lowrie, Frances Steel, and Victoria Haskins, Colonialism and Male Domestic Service across the Asia Pacific (London, 2019), pp. I37-194.

20. Lynn Hollen Lees, Planting Empire, Cultivating Subjects (Cambridge, 2017), pp. I $36-140$,

21. Nathan, Census of British Malaya I92 I, pp. I 8, 29.

22. C.F. Yong, Chinese Leadership and Power in Colonial Singapore (Singapore, 1992), pp. xvi, 38. 
addition to divisions of citizenship, Singapore's Chinese community was divided along lines of dialect, clan, and class, which determined social status and occupation. ${ }^{23}$ Of the major dialect groups, the Hokkiens were the most prominent, followed by the Teochews, the Cantonese, the Hakkas, and the Hainanese. ${ }^{24}$

Domestic work in Singapore was organized around a hierarchy of race and gender. In I 921 , there were 19,369 domestic servants employed in Singapore. Men made up sixty-four per cent of the servant population, with most drawn from the Chinese community and particularly from the Hainanese dialect group. ${ }^{25}$ Hainanese men worked in the homes of wealthy British, Eurasian, Chinese, Indian, and Arab residents of Singapore where they were employed as cooks and houseboys, as depicted in Figure I. In large households, Chinese men were employed alongside Indian and Malay men, and (in households with children) Chinese ayabs (nannies). ${ }^{26}$ Within Chinese households, young bonded female servants, called mui tsai, were often also present. ${ }^{27}$ As well as working in private homes, Chinese men, described variously as "servants", "houseboys", and "boys" (Figure I), were employed in mess houses (share houses), commercial lodging-houses, and police and army barracks. They also provided personalized care in high-class hotels, such as the Hotel de l'Europe, Raffles, and the Adelphi, where each guest was allocated a "boy" to attend to their particular needs. In addition, they were engaged as general servants within clubs and public houses. ${ }^{28}$

While Hainanese men predominated in domestic work in Singapore, men from the Hokchia dialect group also worked as servants. ${ }^{29}$ Hokchia domestic workers commanded lower wages than Hainanese men, receiving between \$ Is and $\$ 25$ in wages a month in the mid-I 920 s, depending on their role. ${ }^{3 \circ}$ In the same period, Hainanese servants could command between $\$ 20$ and $\$ 35$ per month. $^{\text {II }}$

23. Yen Ching-Hwang, "Class Structure and Social Mobility in the Chinese Community in Singapore and Malaya I 800-191 I", Modern Asian Studies, 21:3 (1987), p. 4 I 8.

24. Edwin Lee, "Community, Family, and Household", Ernest Chew and Edwin Lee (eds), A History of Singapore (Singapore, 199I), p. 247.

25. Nathan, Census of British Malaya I92 I, pp. I8, 83, 239.

26. Claire Lowrie, Masters and Servants (Manchester, 2016), p. 30.

27. Rachel Leow, “'Do You Own Non-Chinese Mui-Tsai?': Reexamining Race and Female Servitude in Malaya and Hong Kong, 1919-1939", Modern Asian Studies, 46:6 (2012), pp. $1746-1747$.

28. See Annie Brassey, A Voyage in the "Sunbeam" (New York, I88I), pp. 409-410; C.D. Mackellar, Scented Isles and Coral Gardens (London, I9I 2), p. 74; John Hutchison MacCallum Scott, Eastern Journey (London, I939), pp. 55-56.

29. Lee, "Community, Family, and Household", p. 247.

30. Coroner's Court, Coroner's Inquests and Inquiries, no. I2, Oct-Dec 1925 , NAS: ADo25.

31. R.L. German, Handbook to British Malaya (London, 1926), p. 46. 


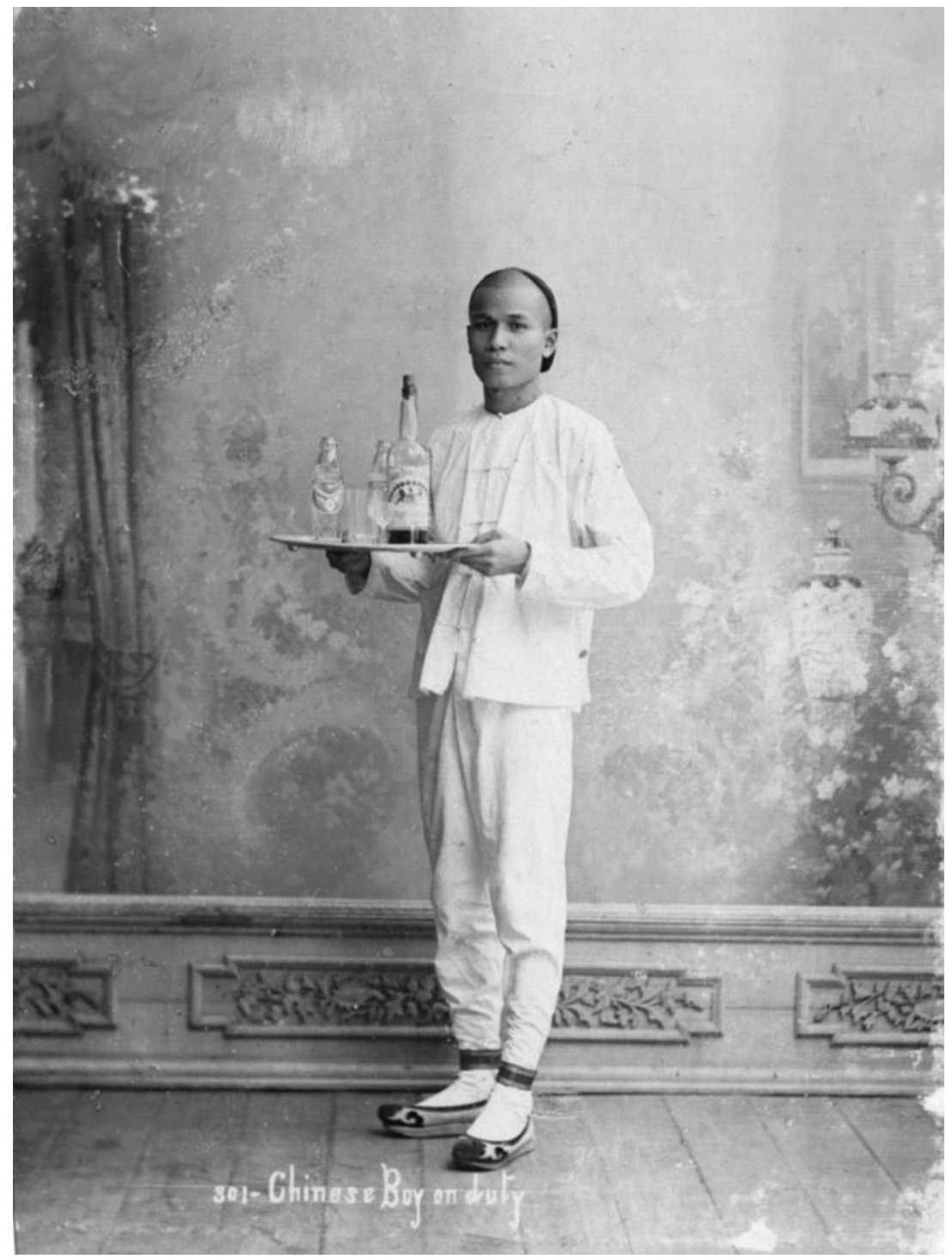

Figure I. "30I - Chinese Boy on duty", Lambert and Co, Singapore, c. 1900.

University of Leiden, Royal Netherlands Institute of Southeast Asian and Caribbean Studies, 50196.

The predominance of Hainanese men in domestic service is partly explained by the tendency for occupations in colonial Singapore to be organized according to dialect group. It was also a consequence of familial patterns of migration, with some domestic servants having followed in the footsteps of male 
relatives. ${ }^{32}$ The cohesiveness of Singapore's Hainanese servant class was fostered by their membership of the Hainanese kongsi, which colonial officials labelled a "secret society". ${ }^{33}$ The kongsi helped men find work, played a role in setting standards for working conditions and wages, assisted in the event of unemployment or retirement, and occasionally facilitated (or threatened to facilitate) collective action on behalf of domestic workers. ${ }^{34}$

One area in which the Hainanese kongsi asserted its power was in relation to the campaign for servant registration. Calls for the government to regulate the domestic servant population had been a feature of the political landscape since the r 880 s. Between I9I I and I913, British residents of Singapore (supported by the local press) organized a concerted campaign calling for servant registration. They wanted a system whereby employers were provided with the personal and (potentially) criminal histories of prospective Chinese servants. While a bill for servant registration was passed by the Legislative Council in I9 I 3 , it ultimately did not come into force due to the combined threat of massstrike action facilitated by the Hainanese kongsi and a lack of will on the part of government to enforce the legislation. ${ }^{35}$

By the late I920s, the nature of the domestic workforce was changing. Indoor domestic work gradually became the domain of Chinese women immigrants, referred to as maijie or "black-and-white amabs" (a reference to the colour of their uniforms), who gradually displaced the Chinese houseboys of the previous era. ${ }^{36}$ By I93 I, domestic service had become the most popular occupation for Chinese women in Singapore and, by the I940s, female domestics constituted seventy per cent of the workforce. ${ }^{37}$ Where men were employed as private servants they tended to be confined to outdoor tasks as gardeners or drivers. ${ }^{38}$ The decline of male servants in private households in Singapore was part of a slow process of feminization of domestic labour across the Asia-Pacific region during the $1930{ }^{39}{ }^{39}$ In contrast to private service,

32. See, for example, NAS, “Transcript of Interview with Lim Ming Joon”, ${ }_{23}$ September 1983 , ACC $000334 / 07$, p. 33; “Transcript of Interview with Wong York Beng”, I986, NAS: ACC 000668 , disc I.

33. Carl Trocki, Opium and Empire: Chinese Society in Colonial Singapore, I800-1910 (Ithaca, NY, I990), p. I I.

34. Peleggi, "The Social and Material Life of Colonial Hotels, p. 2 I; Martínez et al., Colonialism and Male Domestic Service, pp. 199-200.

35. Lowrie, Masters and Servants, pp. 90-92, I I 8-I I 9, I44-I45.

36. Kenneth Gaw, Superior Servants: The Legendary Cantonese Amabs of the Far East (Singapore, I988), p. I I I.

37. Sharon Lee, "Female Immigrants and Labor in Colonial Malaya", International Migration Review, 23:2 (1989), p. 323.

38. Lowrie, Masters and Servants, p. $3 \mathrm{I}$.

39. Martínez et al., Colonialism and Male Domestic Service, pp. 222-223. 
however, men continued to be employed in domestic work in hotels, clubs, and bars well into the 1940 s. $^{40}$

The available evidence does not provide a clear picture of the frequency of violence within the domestic service relationship in Singapore. In terms of the everyday experiences of Chinese men working as servants between I910 and 1939, the acts of intense violence studied in this article were not the norm. Murders by stabbing and suffocation, causing grievous hurt by bludgeoning victims, suicides and attempted suicides by swallowing acid - the evidence suggests that these were exceptional events. The lack of reported violent crime reflects the larger patterns of crime in Singapore, where larceny rather than assault or murder was the most common chargeable offence committed. ${ }^{4 \mathrm{I}}$ Certainly, when it came to servants, theft was regularly reported in the local newspapers. ${ }^{42}$ At the same time, however, oral histories and memoirs from domestic servants and their employers in colonial Singapore suggest that physical violence, sexual violence, and the threat of violence were commonplace, ${ }^{43}$ as they were in other colonial contexts. ${ }^{44}$ It is likely that the small number of convictions for such crimes in Singapore is more indicative of underreporting, rather than an absence of violence.

This article does not aim to understand how central a role violence played in the domestic service relationship. Rather, I am interested in what three murder convictions can tell us about the "social materiality" of domestic workers" lives. ${ }^{45}$ The murder of Sarah Liebmann and Emil Landau in I91 8 occurred at a modest hotel in downtown Singapore. The stabbing death of Wong Chee in 1925 took place at a Japanese shipping company mess, located on the city end of Orchard Road. Teo Chye Neo was murdered at her home in the Straits Chinese suburb of Geylang in 1933. The information generated by the colonial state, in terms of investigating these crimes and convicting and sentencing those responsible, can be mined for evidence of the diverse

40. Lowrie, Masters and Servants, p. 107.

4I. C.M. Turnbull, A History of Singapore, I8I9-1975 (Kuala Lumpur, 1977), p. I35; Robert L. Jarman (ed.), Annual Reports of the Straits Settlements 1855-194I. Volume 7: 19I5-192I (London, 1998), pp. 247-292; Annual Reports of the Police Force and State of Crime for 1925 , 1926, and 1927, NAS: PPMS 3 i/File 4.

42. See, for example, "A Godown Pilferer: Chinese Houseboy Caught in the Act", Straits Times, I7 June I9 I 5; "Servant's Theft of \$2,700: Subsquent Arrest on Johore Causeway”, Straits Times, 25 June 1928; "Houseboy Steals from His Employer", SFPMA, i9 April 1939.

43. See "Transcript of Interview with Lim Ming Joon", pp. 25-26; Janet Lim, Sold for Silver (Singapore, 2004), pp. 35, 38; Lucy Lum, The Thorn of Lion City (London, 2007), p. I60.

44. See Victoria Haskins, “Down the Gully and Just Outside the Garden Walk': White Women and the Sexual Abuse of Aboringial Women on a Colonial Frontier", History Australia, I0:I (20I3), pp. II-I5; Fae Dussart, “'Strictly Legal Means': Assault, Abuse and the Limits of Acceptable Behaviour in the Servant/Employer Relationship in Metropole and Colony i $850-$ I 890", in Haskins and Lowrie (eds), Colonization and Domestic Service, pp. I 53-171; Badassy, “'And My Blood Became Hot!”, pp. 73-106.

45. Yeoh, Contesting Space in Colonial Singapore, p. 325. 
working and social lives of Chinese male servants. By reading this material against the grain, we catch glimpses of how servants moved around the city, where they lived, where they slept, what they did in their leisure time, and the factors that resulted in these workers becoming victims, perpetrators, and witnesses of violent crime.

These cases also provide insight into the experience of domestic workers within Singapore's criminal justice system. In Singapore, the jury system was adopted for criminal cases only and operated (as in Hong Kong) according to English legal principals. However, while in England twelve jurors were required to sit on criminal cases, in Singapore only seven were required and a mere six in Hong Kong. ${ }^{46}$ Another crucial difference from the English system was that verdicts were determined by a majority decision, even in capital cases. In England, a unanimous verdict from all twelve members of the jury was required in all cases. In Hong Kong, a unanimous discussion was required for capital cases. ${ }^{47}$

As Christopher Munn has illustrated in relation to Hong Kong, the colonial court system was set up in a way that made it easier to convict those accused of serious crimes than it would have been in England. In addition, the racialized and class prejudices that were ingrained within the legal system tended to result in harsh sentences for Chinese workers. ${ }^{4}$ Chinese workers were also disadvantaged by the fact that the court system operated on the basis of the English language. The court interpreter had the potential to "influence the course of the trial" in ways that did not necessarily result in just outcomes. ${ }^{49}$ The three murder cases examined here cannot be taken to be representative in terms of the operation of Singapore's legal system. Nonetheless, they indicate that Munn's findings in relation to Hong Kong may also hold true for Singapore.

Chinese lawyers were employed in Singapore from the 1890 and juries included adult men from the "European", Chinese, Malay, Indian, and Eurasian communities. ${ }^{\circ}{ }^{\circ}$ However, for important trials (such as murder trials), "special juries" were established with jurors selected on the basis of "superior qualifications in terms of property, character or education". ${ }^{\mathrm{I}}$ While the names of the jurors were not provided in the press accounts of the trials, they were likely of middle- or upper-class origin. Judges in Singapore were members

46. Chandra Mohan Shunmugam and Sukumaran Ramankutty, "The Introduction and Development of Trial by Jury in Malaysia and Singapore”, Malaya Law Review, 8 (I966), pp. 270-271; Christopher Munn, "The Criminal Trial under Early Colonial Rule", in Tak-Wing Ngo (ed.), Hong Kong's History (London, 1999), p. 48.

47. Shunmugam and Ramankutty, "The Introduction and Development of Trial by Jury", p. 270.

48. Munn, "The Criminal Trial under Early Colonial Rule", pp. 52-53.

49. Ibid., p. 48 .

50. C.M. Turnbull, The Straits Settlements, I826-67 (London, I972), pp. 72, I 35 .

5. Shunmugam and Ramankutty, “The Introduction and Development of Trial by Jury”, p. 270. 
of the British ruling elite. ${ }^{52}$ In this context, it is not surprising that all three cases examined in this article led to death sentences, despite each of the accused pleading "not guilty" to the charge of murder. While the jury decision was unanimous in the Liang case, the verdicts were six to one in relation to both Ee and Yeo.

\section{HOTEL SERVANTS AND THE GLOBE HOTEL MURDERS OF I 9 I 8}

The Globe Hotel, where Liang Ah Tee murdered Sarah Liebmann and Emil Landau, was located on North Bridge Road in the downtown area of Singapore. The section of North Bridge Road on which the hotel was situated ran parallel to Victoria Street and Beach Road. This was a crowded urban area in which low-class brothels and opium houses were common. ${ }^{53}$ They were patronized by the Chinese workers who lived in downtown Singapore, often residing in shop houses that combined work and residence. ${ }^{54}$ The area around Victoria Street and North Bridge Road in particular was dominated by rickshaw workers and their lodgings (Figure 2). ${ }^{55}$ Liang himself had previously worked as a rickshaw puller before taking up a position as a bar boy at the Globe. He resided with other rickshaw men at 65 Bain Street, only 250 metres from the hotel. ${ }^{56}$

While the Globe Hotel might have been located in a somewhat disreputable area, Liebmann and her establishment were represented favourably in the local English press. The Straits Times, the mouthpiece of the British elite of Singapore society, described Liebmann as a "good sort" who "did not have a single enemy". The hotel, fraternized largely by visiting sailors, was praised as:

[...] a well conducted bar, the proprietress being a "stickler" for quiet behaviour on the premises. She always saw that the sailors, naval and mercantile, left her premises without having had too much to drink and there was always the attraction of some music to keep the men happy. ${ }^{57}$

The positive description of Liebmann in the press is somewhat surprising considering that she was a single European woman and the owner of a hotel. European "barmaids" were sometimes portrayed as a threat to colonial morality and authority. ${ }^{58}$ Liebmann's respectability was perhaps related to her

52. Helena H.M. Chan, The Legal System of Singapore (Singapore, I995), p. I23.

53. Warren, $A b \mathrm{Ku}$ and Karayuki-San, pp. $4^{2-43}$.

54. Yeoh, Contesting Space in Colonial Singapore, p. 46.

55. Warren, Rickshaw Coolie, p. 40.

56. "Death of a Female and Male Austrian Jew, Coroner's Court, Coroner's Court Inquiries, Jan to Dec 1918, Singapore”, 26 August 1918, NAS: ADo63.

57. "Globe Hotel Murders: Development of Mysterious Crime", Straits Times, 30 August 191 8.

58. Peleggi, "The Social and Material Life of Colonial Hotels", pp. I6-i 7. 


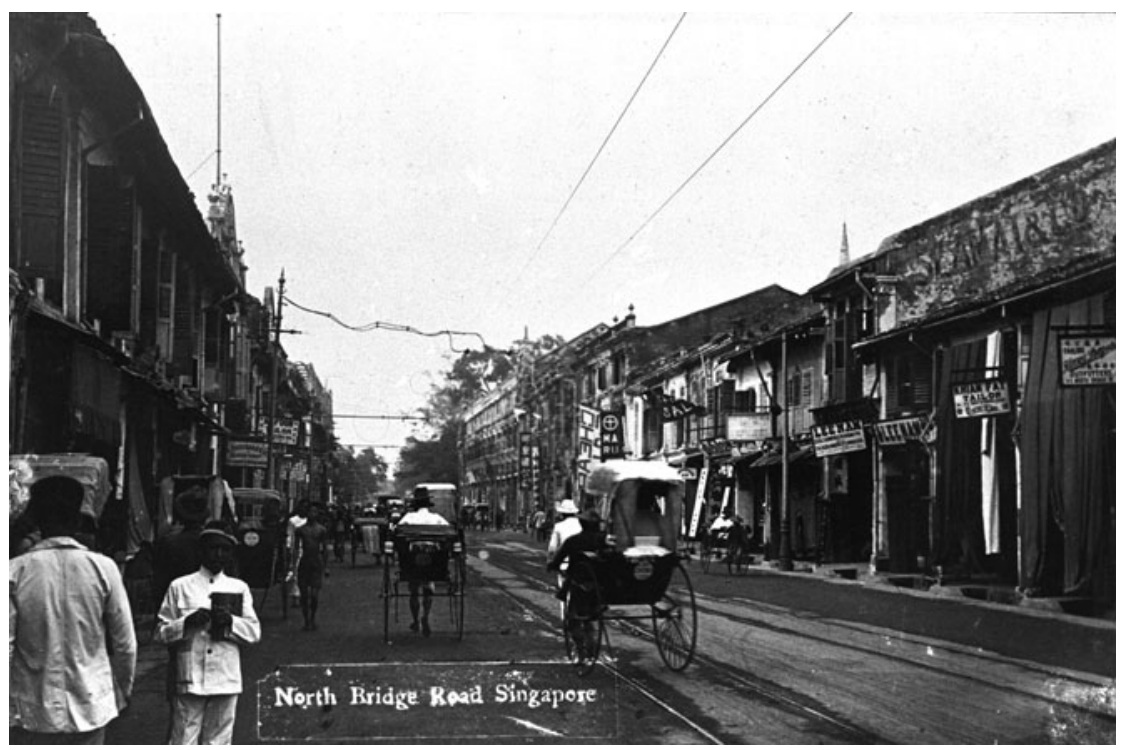

Figure 2. North Bridge Road Singapore, I9Ios.

Lim Kheng Chye Collection, courtesy of National Archives of Singapore. 19980005879-0017.

status as a widow and her class position. She was fifty-nine and had lived in Singapore for six years, having moved to the city following the death of her Russian husband in Penang. Liebmann and her elderly lodger, Landau, were both Austrian Jews and were part of the second wave of Jewish migration to Singapore between I88I and I9I $4 .{ }^{59}$ The Jewish community was a socially diverse one, with Liebmann and Landau part of the well-to-do commercial class. $^{60}$

While no specific details about Liang's personal history are provided in the criminal archives, he was typical of Hokchia migrant men who, as late arrivals to Singapore, tended to take up the least sought after occupations, such as rickshaw pulling. ${ }^{61}$ Numerous photographs and postcards featuring rickshaw workers, such as Figure 3, are suggestive of the hard physical labour that the job involved and the limited returns that it provided. Liang's lowly status is further demonstrated by his meagre world possessions, which the police detailed following a search of his dwelling. As was common for men of the rickshaw puller class, Liang owned one box of possessions that was stored under his bed in the small room he shared with other men. ${ }^{62}$ In addition, he

59. Joan Bieder, The Jews of Singapore (Singapore, 2007), p. 29.

60. "The Assizes: Globe Hotel Murders", Malaya Tribune, 24 September 1918.

6r. Lee, "Community, Family, and Household", p. 247.

62. Warren, Rickshaw Coolie, p. 44. 


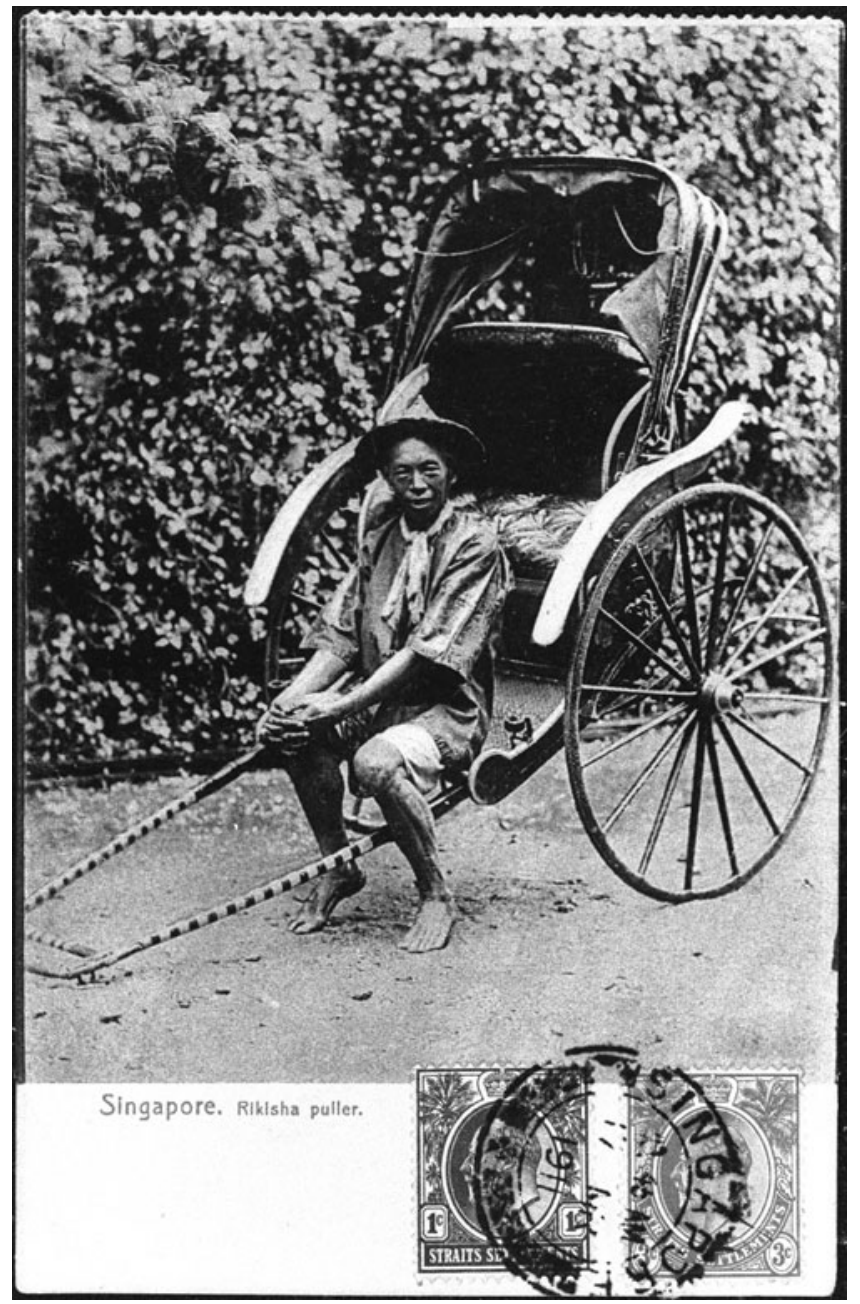

Figure 3. Postcard of a rickshaw puller from Singapore published by Max H. Hilckes, c. I9 Iо. Courtesy of the National Archives of Singapore, I9980005094-0I07.

owned, according to Detective Inspector Alfred Lancaster, "an old hat" and "a bundle of clothes hanging on a nail over the accused's bed" and a pair of slippers. ${ }^{63}$

The opportunity for Liang to move up the social ladder and become a hotel servant was presented by his roommate and friend, Ah Lay. Ah Lay had been

63. "Globe Hotel Murders: What Was Found at Accused's Lodgings", SFPMA, 27 September I9I8. 
working at the Globe for a number of years. However, sick with an undisclosed illness, he was unable to continue his job and asked Liang to take it over. ${ }^{64}$ Chinese domestic workers were regularly recruited through word-of-mouth, with jobs often passed from one friend or family member to another. ${ }^{65}$

While it might have been a step-up from being a rickshaw "coolie", Liang described his mere ten days of working life at the Globe as unhappy ones. In his original statement of confession (written with the assistance of a police translator), he maintained that he had murdered Liebmann after she abused him. As he put it:

On the night of August 25, I was asked by the deceased woman to fetch some liquor and I brought the wrong stuff. She abused me and told me that I could not do my work. At eleven o'clock the shop was closed and I told the deceased woman that I could not come the next day. She got angry and struck me and then I hit her with a peace [sic] of iron on the nose and she fell down. I then strangled her with a piece of cloth. ${ }^{66}$

Liang claimed that he also strangled the eighty-year-old Landau following a violent altercation with the man that night. By the time of the murder trial, however, Liang had retracted his original confession, claiming that his statement to Detective Inspector Lancaster had been made under duress. As Liang put it to Justice Ebden at the murder trial:

[Lancaster] told me if I repeated to the magistrate what I told him he would supply me with chandu cigarettes and other things in prison. He also told me that if I made a statement before the magistrates I would be discharged and called as a witness for the Crown, and Twa Bok would be convicted. I agreed. ${ }^{67}$

Lancester's offer of “chandu cigarettes" suggests that Liang was an opium smoker. This is perhaps not surprising. Working in the downtown area, Liang would have had easy access to opium houses and the majority of Hokchia rickshaw workers used the drug. ${ }^{68}$ While it was portrayed by colonial authorities as a Chinese vice, opium was entirely legal in Singapore at the time. Indeed, by the r9ros, the Straits Settlements government held a monopoly on the sale of the drug, the revenue from which made an important contribution to the government coffers. ${ }^{69}$

64. "Globe Hotel Murders: Accused on His 'Confession”", SFMA, 3 October I9I 8; "Globe Hotel Murders: Accused Sentenced to Death", SFPMA, 3 October I918.

65. Julia Martínez and Claire Lowrie, "Transcolonial Influences on Everyday American Colonialism: The Politics of Chinese Domestic Servants in the Philippines", Pacific Historical Review, 81:I (2012), pp. 525-526.

66. "Globe Hotel Murders", Straits Times, 28 September 1918.

67. "Globe Hotel Murders: Accused on His 'Confession'”, SFPMA, 3 October 1918.

68. Warren, $A b \mathrm{Ku}$ and Karaynki-San, pp. 239-236.

69. Trocki, Opium and Empire, pp. I-2, 234. 
Liang's claim of duress also illuminates his broader social circle and the financial pressures that Hokchia men endured. Twa Bok was a rickshaw puller who lived with Liang and Ah Lay at the Bain Street lodgings. Liang claimed that he, Ah Lay, and Twa Bok had discovered the bodies of Liebmann and Landau on the morning after the murder. The three men then took \$3I.50 (Straits) from the premises, removed a ring from Liebmann's finger, and unscrewed the earrings from her ears. ${ }^{70}$ The money was found during the initial search of Liang's room by Lancaster. The jewellery was only located after Liang himself suggested Lancaster return to the Bain Street lodgings and search inside his slippers. ${ }^{71}$ Ah Lay died during the course of the trial and was unable to provide a statement. Twa Bok, however, maintained that he was not involved with the theft and had tried to persuade Liang against it. $^{72}$

Considering the small amount of money and goods that were taken, a financial motive for double murder does not seem to be all that convincing. However, the prosecution asserted that Liang had envisioned a far greater monetary reward. The hotel safe contained $\$_{3}, 850$ and the three men had allegedly tried to prise it open and, when that proved impossible, they took it from the premises. ${ }^{73}$ For the jury, this was a compelling motive. They unanimously declared Liang guilty of murder after only five minutes of deliberation. ${ }^{74}$ When the judge asked the prisoner if he had anything to say, Liang once again asserted his innocence, claiming, "[i]f I committed the murder I would have run away [...] I would not have gone back to work the next morning". An unmoved Justice Ebden donned the black cap and passed a sentence of death. ${ }^{75}$ For his part in the crime, Twa Bok was arrested by police on a banishment warrant and soon after removed from the colony. ${ }^{76}$

In the press coverage of the murders, one writer, using the pseudonym " $\mathrm{A}$ Hylam", noted that Liang was "not a Hylam, but a Hokchia" and that "Hylam" (Hainanese) "boys" would "never commit this kind of hideous crime", in part because the salaries they received were much more generous. ${ }^{77}$

70. “Globe Hotel Murders", Malaya Tribune, 5 September i9r 8.

71. "Globe Hotel Murders: Futile Attempt to Open Safe", SFPMA, 26 September i 91 8; "Globe Hotel Murders”, Straits Times, 28 September I9I 8; Coroner's Court, Coroner's Court Inquiries, Jan to Dec 1918, Singapore 26 August 19i 8; "Death of a Female and Male Austrian Jew", NAS: AD०63.

72. "Globe Hotel Murders: What Was Found at Accused's Lodgings", SFPMA, 27 September I9I8.

73. "The Assizes: Globe Hotel Murders", Malaya Tribune, 24 September 1918; "Globe Hotel Murders: Futile Attempt to Open Safe”, SFPMA, 26 September 191 8; "Globe Hotel Murders", Straits Times, 28 September 1918; "Globe Hotel Murders: Accused Man Executed”, SFPA, 3 I October 1918.

74. "Globe Hotel Murders”, Straits Times, 28 September 19r 8; “Globe Hotel Murders: Accused Sentenced to Death", SFPMA, 3 October I918.

75. "Globe Hotel Murders: Accused Sentenced to Death", SFPMA, 3 October I9r 8.

76. "Untitled", Straits Times, 3 October I918.

77. "Exculpating the 'Boy"”, SFMPA, ig September I9 8. 
In some cases, Hainanese commanded double the wage of Hokchia servants. ${ }^{78}$ While the writer was quite correct in drawing attention to the very different conditions of employment for Hainanese men in elite homes and high-class hotels, the capacity for murder was not (of course) determined by ethnicity. Nor did all Hainanese domestic workers enjoy high wages and good working conditions, as the Onan Road Murder of 1933 illustrates.

\section{WORK AND DEATH IN A STRAITS CHINESE HOUSEHOLD: THE ONAN ROAD MURDER, I 933}

Not far from downtown Singapore, Geylang, in the north-east of the city, was a traditional enclave for the Malay and Arab communities, with the land dedicated to the cultivation of coconut plantations. In the I920s and I930s, the district underwent major development as roads, shophouses, and terraces began to be established. At that time, significant numbers of Straits Chinese families moved into the area. ${ }^{79}$ It was in one such household that a young Hainanese servant, Yeo Tin Keng, was employed by a Straits-born Hokkien couple in 1933. Yeo was the only servant employed within the household on 40-A Onan Road, a sandy lane off Geylang Road. ${ }^{80}$ On the morning of 22 June, after his master had left for work, fourteen-year-old Yeo stabbed to death his mistress, Teo Chye Neo, in front of her five-year-old daughter. The screams of Teo alerted passers-by and while Yeo attempted to flee, he was captured and taken to Katong police station. The twenty-seven-year-old Teo, who was pregnant at the time of her death, died at the scene. She was found "lying in a pool of blood" with at least ten stabs wounds to the face and neck. ${ }^{81}$

Unlike the previous murder studied in this article, the inquest records for the Onan Street murder are not held in the National Archives of Singapore. The Coroner's Court Master Book includes only a short reference to the case, with the cause of death described as shock due to stab wounds and a finding of murder recorded. ${ }^{82}$ The case was, however, reported in considerable detail in the newspapers.

Considering that Yeo murdered a pregnant woman, and did so in front of her young daughter, the measured way in which the case was reported is surprising. The articles that described the murder and Yeo's trial focused on his

78. Coroner's Court, Coroner's Inquests and Inquires, no. I2, Oct-Dec 1925, NAS: ADo25; German, Handbook to British Malaya, p. 46.

79. Norman Edwards and Peter Keys, Singapore: A Guide to Buildings, Streets, Places (Singapore, I988), p. 30 I.

80. Savage and Yeoh, Toponymics, p. 384.

8 I. "Stabbed Woman Dies Unrelieved: Alleged Brutal Attack by Servant”, SFPMA, 8 July i933;

"Onan Road Crime", Malaya Tribune, 23 June 1933; "Coroner's Inquiry: Hylam Youth on Murder Charge", Malaya Tribune, 7 July i 933.

82. "Inquest Number 300, Coroner's Court, Master Book, I925-1952", NAS: ACC ADo65. 
young age of fourteen and the systematic abuse that he experienced in the Onan Road household. Neighbours interviewed during the murder trial maintained that Teo was "a woman of violent temper" and that she had frequently abused and scolded Yeo. ${ }^{83}$ Teo's five-year-old daughter was also interviewed at the trial and she confirmed that Yeo was subjected to daily abuse, including on the day of the murder when her mother slapped him in the face. In his own (translated) account, Yeo maintained that:

The deceased used to scold and abuse me and hit me with a piece of wood, clogs and shoes. If she found a little dust on the chair, she would abuse me [...] Sometimes she spat on me. I was struck on the arms and forehead with a piece of firewood.

On the day of the murder, Yeo claimed that Teo had hit him because the floors were not clean. ${ }^{84} \mathrm{He}$ tried to return to his job but his mistress continued beating him and kicking him before grabbing a knife and running at him. According to Yeo's account, a struggle ensued and he stabbed her in the face before she fell on the knife. He panicked, took the backdoor key from her bedroom, opened the door and ran. ${ }^{85}$

It was not entirely uncommon for Chinese men who had been "reprimanded", physically threatened, or "abused" to retaliate with violence. ${ }^{86}$ Yeo suffered not only from daily abuse, but also from social isolation. He was locked in the house and prevented from leaving to socialize with his friend and his brother, who also resided in Singapore. ${ }^{87}$ For Chinese domestic workers, visiting family members or frequenting coffee houses was important in terms of leisure. ${ }^{88}$ Such outlets allowed Chinese men to escape the "disciplinary gaze of their employer", providing opportunities for them to socialize in groups, complain about the demands of the job and seek emotional support. ${ }^{89}$

While Hainanese hotel workers enjoyed the protection and camaraderie of the Hainanese kongsi, Yeo had been recruited informally. He came to work for Teo after she approached him at the Katong Market with an offer that was a \$2 increase on the $\$ 4$ a month salary he received in his previous job as a servant at

83. "Five Year Girl in Court: Pathetic Tale of Mother's Death", SFPMA, is September 1933.

84. "Onan Road Murder: Hylam Boy Guilty”, Malaya Tribune, i6 September 1933.

85. "Five Year Girl in Court: Pathetic Tale of Mother's Death", SFPMA, is September I933; "Stabbed to Death: Woman's Hylam Arrested", Straits Times, 22 June 1933; "Geylang Murder Case: Accused Cook-Boy Now in Hospital”, Straits Times, 23 June 1933.

86. See, for example, "Legal Intelligence: Police Courts - the Orchard Road Affray", Malaya Tribune, 2 November 1916; "European Lady's Escape: Threatened with an Axe by Hylam Cook”, Straits Times, 29 September 1922.

87. "Onan Road Murder: Hylam Boy Guilty”, Malaya Tribune, I6 September 1933.

88. See, for example, "Legal Intelligence: Police Courts - the Orchard Road Affray", Malaya Tribune, 2 November 1916; "The Assizes: Sequel to Affray in Killiney Road”, SFPMA, 7 May I925.

89. Brenda S.A. Yeoh and Shirlena Huang, "Negotiating Public Space: Strategies and Styles of Migrant Female Domestic Workers in Singapore”, Urban Studies, 35:3 (1998): pp. 588, 590-591. 
the Joo Chiat English School. This was a very small wage compared with the $\$ 20$ to $\$ 30$ dollars a month that Hainanese servants in other households and hotels were commanding. In any case, in the three months that he was employed at Onan Street, Yeo claimed that he had received no wages at all..$^{\circ}$

This case illustrates the degree to which the working conditions of Chinese male servants were unregulated. In their campaigns for servant registration, employers claimed that the lack of governmental regulation left them vulnerable to exploitation and abuse by their Chinese staff. ${ }^{91}$ As Yeo's story suggests, however, domestic workers were perhaps more vulnerable to exploitation than their employers. In light of Yeo's circumstances, his defence Lawyer, $\mathrm{Mr}$ Mitter, urged the jury to return a finding of self-defence. The jury members must have found the claims of abuse compelling. They deliberated on the verdict for over an hour, with the foreman asking for clarification from the judge as to "how long a time would be implied in the word 'sudden' as regards to the question of sudden provocation". While the jurors were sympathetic, they found Yeo guilty of murder by a verdict of six to one. As Yeo was underage, he was sentenced to "be detained pending His Majesty's pleasure", at which point he disappeared from public discourse..$^{2}$

The first two cases of murder examined in this article considered servant violence towards their employers. The final case to be considered, the Orchard Road Murder of 1925 , involved a conflict between two domestic workers.

\section{THE ORCHARD ROAD MURDER OF I 925 : \\ VIOLENCE BETWEEN SERVANTS}

On 5 November 1925 at around seven o'clock in the evening, a thirty-year-old Hokchia tukan ayer (water carrier) by the name of Ee Ah Lak murdered Wong Chee, a Hokchia houseboy. The men had worked and lived together for two years within the mess of the NYK Japanese shipping company located on 106 Orchard Road. At the northern end of Orchard Road lay the suburb of Tanglin, which encompassed the Botanical Gardens and was home to the British colonial elites. ${ }^{93}$ Here, they resided in leafy Anglo-Indian bungalows with their household staff living onsite in servants' quarters. ${ }^{94}$ Numerous servants also lived within servants' quarters in the mansions of wealthy Straits Chinese and overseas Chinese located in the vicinity of Orchard Road on

90. “Onan Road Murder: Hylam Boy Guilty”, Malaya Tribune, I6 September 1933.

91. Lowrie, Masters and Servants, pp. 90-92.

92. "Onan Road Murder: Hylam Boy Guilty”, Malaya Tribune, I6 September 1933.

93. Savage and Yeoh, Toponymics, p. 286; Yeoh, Contesting Space in Colonial Singapore, pp. 225 , 28.

94. See, for example, “And His Excellency’s Houseboy”, Straits Times, I 2 September 1937. 


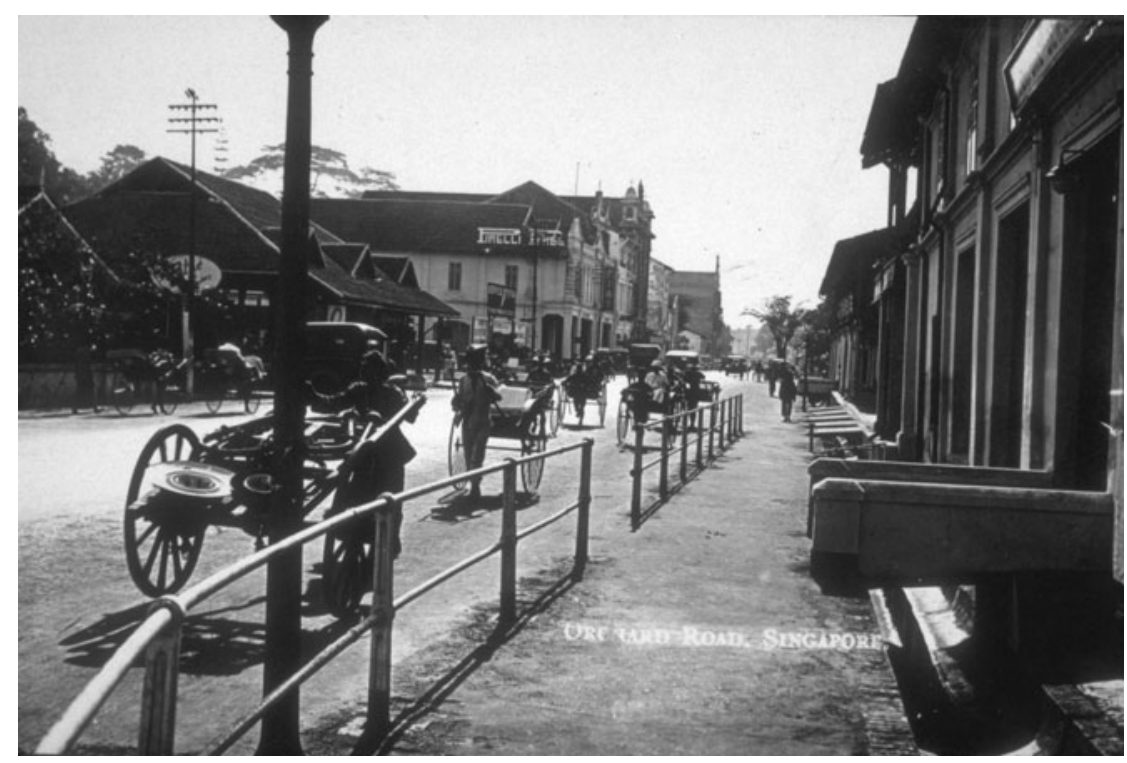

Figure 4. Postcard of Orchard Road towards the direction of Dhoby Ghaut, Singapore, c. 1920. Robert Feingold Collection. Courtesy of National Archives of Singapore, 19980005 107-0086.

illustrious streets such as Devonshire Road, St Thomas Walk, Scotts Road, and Emerald Hill. ${ }^{95}$ Rather than being surrounded by bungalows and mansions, however, the NYK mess house was at the south-eastern end of Orchard Road, a busy commercial area (Figure 4). The mess house was within walking distance of an area called Dhoby Ghaut. Here, Indian laundry workers (dhobies) worked in commercial laundries, washing clothes using water from Stamford Canal..$^{6}$

The murder that took place in the NYK residence was a vicious one. Ee stabbed nineteen-year-old Wong twenty-one times in the abdomen, chest, and extremities with a dual-edged Japanese knife. Shortly after the murder, Ee presented himself to the Orchard Road Police station. Dressed in bloody clothes and carrying the knife, he confessed to the crime. The police rushed to the NYK mess and arranged transport for Wong to the Tan Tock Seng Hospital. By the time he arrived at the hospital, however, Wong was unconscious. He died of his injuries shortly after. ${ }^{97}$

95. See, for example, “Transcript of Interview with George Seow”, 2002, NAS: 002642.

96. Savage and Yeoh, Toponymics, p. i Iо.

97. Coroner's Court, Coroner's Inquests and Inquiries, no. I2, Oct-Dec I925, NAS: ADo25;

"Orchard Road Murder", Malaya Tribune, 6 November 1925; "Boy Kills Tukan Ayer: Fatal

Quarrell in Japanese Mess”, Straits Times, 6 November 1925. 
The first police officer who arrived at the scene of the murder was a Malay sub-Inspector. He interviewed the mortally wounded Wong in Malay about what had happened. According to this account, Wong claimed that he had asked Ee to return twenty dollars that he had lent him some weeks ago. In response, Ee became angry and stabbed Wong. The other houseboy and cook employed in the mess confirmed, as did Wong's mother, that Ee owed Wong money.

Chinese labour migrants to Singapore typically followed the lead of male family members, such as brothers and uncles. ${ }^{98}$ Wong was somewhat unusual for a Chinese migrant in that his mother lived in Singapore. She resided on Victoria Street, about a twenty-minute walk away from the Orchard Road mess house. While other Chinese men employed as domestic workers in Singapore remitted money to China to support relatives, Wong supported his mother in Singapore. ${ }^{99}$ In her interview at the inquest, Wong's mother confirmed that her son had lent Ee money, but disputed the amount. She explained that Wong usually gave her fifteen dollars a month, which was three quarters of his monthly wage. In the previous month, however, he had only given her ten dollars, having lent Ee the rest. ${ }^{100} \mathrm{It}$ is true that tensions arising from debts owed or threats to financial stability drove domestic workers to engage in violent acts in other households. ${ }^{101}$ In the case of the Orchard Road murder, however, the money that Ee owed Wong does not seem to have been the catalyst for the stabbing.

The cook, the houseboy, and Wong's mother maintained that Wong had only limited Malay and that this may have resulted in a miscommunication with the attending police officer. They explained that Ee and Wong were good friends, who always socialized together and had shared a room for the past eleven months. All four of the servants employed in the household were close, having migrated from the same district in China. ${ }^{102}$ The houseboy, who had talked to Wong before he died, maintained that the conflict arose when Ee asked to share Wong's bed and Wong refused. In the small room that they shared, Wong had an iron bed and a mosquito net. Ee had only a green canvas bed, the legs of which were broken. ${ }^{103}$ In his testimony at the inquest, Ee confirmed this basic account but added that Wong had told him he could no longer sleep in the same room and had thrown his pillow and

98. See NAS, “Transcript of Interview with Lim Ming Joon”, 23 September 1983, ACC 000334 / 07, p. 33; “Transcript of Interview with Wong York Beng”, I986, NAS: ACC 000668 , disc I.

99. See "Transcript of Interview with Wong York Beng”, NAS: ACC 000668/02/04; "The Assizes: Shooting and Stabbing Affair", Malaya Tribune, 7 December i9r6.

100. Coroner's Court, Coroner's Inquests and Inquiries, no. I 2, Oct-Dec I925, NAS: ADo25.

ıо . See, for example, "Suddenly Hit: Servant Assaulted by Colleague", Straits Times, 24 November 1932.

102. Coroner's Court, Coroner's Inquests and Inquiries, no. I2, Oct-Dec 1925, NAS: AD 25 . 103. "Orchard Road Murder", Malaya Tribune, 6 November i925; "End of the Assizes: Last Case Being Heard Today", Malaya Tribune, 25 January 1926. 
blankets on the floor. Wong (Ee claimed) then grabbed the knife and attempted to stab Ee. Ee wrestled the knife from him and struck him with it blindly. ${ }^{\mathrm{IO4}}$

It may have been the lack of personal space and the basic furnishings of the servants' quarters that proved a catalyst for violence. It is not clear if Ee's employer (referred to in the records as "the tauke" (towkay/boss) provided him with the canvas bed or if Ee had purchased it himself. What is clear is that Ee could not afford to have the bed repaired. As a water carrier, Ee earned only \$Is per month and was the most easily replaced and least skilled of the household staff. A sense of humiliation and injustice certainly comes through in Ee's account of the murder. This might explain the level of rage involved in the killing, with four stab wounds in Wong's chest delivered with enough force to puncture the lungs. ${ }^{\text {Ios }}$

There is another possibility for motive. The intimate setting of the murder in the bedroom and the accounts that described the men as friendly and constantly in each other's company may suggest that this was an intimate relationship turned sour. In China, unlike the European context, homosexuality was tolerated at least up to the Chinese Revolution of I9 I 2. ${ }^{106}$ Chinese "houseboys" in Singapore, like those in French Indochina, were depicted by European colonists as being open to homosexual liaisons. ${ }^{107}$ Yet, the stigma and secrecy that surrounded homosexuality, and the threat of prosecution for engaging in sodomy, has ensured that definitive proof of same-sex relationships in colonial Singapore is hard to come by. ${ }^{108}$ The possibility that Ee murdered Wong due to the breakdown of an intimate relationship was not one raised in the press or the legal documents. In contrast to the Wong murder case, in two other criminal cases involving Chinese male servants, journalists and lawyers were quick to suggest that the rejection of sexual advances by Chinese women had driven the men to engage in violence. ${ }^{\text {I09 }}$

Regardless of the motive, Ee admitted to stabbing Wong but maintained innocence in relation to the charge of murder. In defending his client at the

104. Coroner's Court, Coroner's Inquests and Inquiries, no. I 2, Oct-Dec I925, NAS: ADo25. "The Assizes: Brutal Murder in Orchard Road", SFPMA, 27 January 1926.

I05. "End of the Assizes: Last Case Being Heard Today", Malaya Tribune, 25 January 1926.

106. Kam Louie, "Chinese and Japanese Global Masculine Identities”, in Kam Louie and Morris Low (eds), Asian Masculinities: The Meaning and Practice of Manhood in China and Japan (Abingdon, 2003), pp. 6-7.

107. Lowrie, Masters and Servants, pp. 7 1-102; Frank Proschan, "Syphilis, Opiomania, and Pederasty': Colonial Constructions of Vietnamese (and French) Social Diseases", Journal of the History of Sexuality, i I:4 (2002), p. 620.

108. Robert Aldrich, Colonialism and Homosexuality (London, 2003), p. i I4; Roland Hyam, Empire and Sexuality: The British Experience (Manchester, I992), p. I44.

I09. “'Boy' Poisoned at French Consul's House: Servants' Quarters Tragedy Inquest”, SPFMA, 7 December 1939; "Girl Blinded by Caustic Soda: Hotel Dhoby Sent to Prison”, SFPMA, 8 December 1932. 
murder trial, which took place on 25 to 26 January 1926, V.D. Knowles argued that provocation by Wong ensured Ee had "entirely lost control of himself". Knowles urged the jury to find him guilty of the lesser charge of homicide. ${ }^{\text {IIO }}$ Only one juror seems to have found that argument convincing, with the remaining six finding him guilty of murder. Justice Deane concurred with the majority verdict and sentenced Ee to death. ${ }^{\text {II }}$ The Coroner's Court records describe his death by judicial hanging three months after the murder of Wong, on 9 February I926. ${ }^{\text {II }}$

\section{CONCLUSION}

The three cases of murder explored in this article challenge us to think about domestic service in new ways. The Globe Hotel murders, the Onan Street murder, and the Orchard Road murder illuminate the diverse situations in which Chinese male servants lived and laboured. Rather than the traditional paradigm of elite white employers and Asian servitors within private homes, we see men defined as servants working in low-class hotels, company messes, and middle-class Straits Chinese households. The stories explored here build on our existing knowledge of the troubled encounters between masters and servants. They also bring to light the personal lives and struggles of domestic workers. The three cases examined in this article highlight Chinese men's personal and family relationships, their struggles to eke out a living, and the material conditions in which they lived.

This article represents a first step towards analysing crimes committed by Chinese male servants in order to document the experiences of a group of workers about which little is known. Chinese male servants laboured largely outside of governmental regulation. The rare cases in which they were convicted of crimes brought them into contact with the power of the colonial state in an unprecedented way. The rich archival materials generated by these moments of regulation provide glimpses into the experiences and perspectives of these men. They also shine a light on the broader social worlds of the residents of colonial Singapore as well as the way in which the justice system operated. Further analysis of the Globe Hotel, Onan Street, and Orchard Road murders using the Chinese-language press, alongside analysis of other serious and petty crimes for which Chinese male servants were convicted, has the potential to shed further light on this group of workers and on the nature of everyday life in the cosmopolitan port city of Singapore.

I I0. “The Assizes: Last Case on the Calendar Reached", Straits Times, 25 January 1926.

I I I. "The Assizes: Death Sentence for Chinese Servant", Straits Times, 26 January 1926.

I I 2. "Inquest Number 76, Coroner's Court, Master Book, I925-1952”, NAS: ACC ADo65. 